\title{
PERAN ORGANISASI PEREMPUAN SIDOARJO DALAM MERESPON KEKERASAN TERHADAP PEREMPUAN DAN ANAK DI SIDOARJO
}

\author{
Nurul Asiya Nadhifah \\ Universitas Islam Negeri Sunan Ampel Surabaya Jl. A. Yani 117 \\ Surabaya. E-mail: nurulasiyanadhifah@uinsby.ac.id
}

\begin{abstract}
This article is the result of the research on the role of the women's organizations in Sidoarjo in responding to violence against women and children in Sidoarjo. The women's organizations in Sidoarjo referred to in this study are Fatayat of NU Branch Sidoarjo, Muslimat of NU Branch Sidoarjo, Regional Administrators Aisyiyah of Sidoarjo, Student Association of Nabhdlatul Ulama (IPPNU) Branch of Sidoarjo and Nasyi'atul Aisyiyah of Sidoarjo. Domestic violence is any act against a person, especially women, which results in physical, sexual, psychological misery or suffering resulting from neglect of the household, including threats to do illegal acts of deprivation or deprivation of liberty within the household. The results of the study concluded that Fatayat of NU, Muslimat, Aisyiyah, Nasyi'atul Aisyiyab and IPPNU had an important role in participating and handling cases of violence against women and children that occurred in Sidoarjo. They realize that women's organizations must respond to community development and needs. They participated with the government in dealing with victims of violence against women and children in Sidoarjo. The handling of cases of violence against women and children is not only in legal protection, but trauma healing assistance to victims is also done so that victims can return to their activities as before the violence occurred.
\end{abstract}

Keywords: Women's Organization, Violence, Women, Children.

Abstrak: Artikel ini merupakan hasil penelitian tentang peran organisasi perempuan Sidoarjo dalam merespon kekerasan terhadap perempuan dan anak di Sidoarjo. Organisasi perempuan di Sidoarjo yang dimaksud dalam penelitian ini adalah Fatayat NU Cabang Sidoarjo, Muslimat NU Cabang Sidoarjo, Pengurus Daerah Aisyiyah Sidoarjo, Ikatan Pelajar Putri Nahhdlatul Ulama' (IPPNU) Cabang Sidoarjo dan Nasyi'atul Aisyiyah Sidoarjo. Kekerasan rumah tangga adalah setiap perbuatan terhadap seseorang terutama perempuan yang berakibat timbulnya kesengsaraan atau penderitaan secara fisik, seksual, psikologis dan penelantaran rumah tangga termasuk ancaman untuk melakukan perbuatan pemaksaan atau perampasan kemerdekaan secara melawan hukum dalam lingkup rumah tangga. Hasil penelitian menyimpulkan bahwa Fatayat NU, Muslimat NU, Aisyiyah, Nasyi'atul Aisyiyah dan IPPNU mempunyai peran yang penting dalam ikut serta menangani kasus kekerasan terhadap perempuan dan anak

AL-HUKAMA

The Indonesian Journal of Islamic Family Law Volume 08, Nomor 02, Desember 2018; ISSN:2089-7480 
yang terjadi di Sidoarjo. Mereka menyadari bahwa organisasi perempuan harus merespon terhadap perkembangan dan kebutuhan masyarakat. Mereka ikut serta bersama pemerintah menangani korban kekerasan terhadap perempuan dan anak yang ada di Sidoarjo. Penanganan kasus kekerasan terhadap perempuan dan anak tidak hanya dalam perlindungan hukum saja, akan tetapi pendampingan trauma healing terhadap korban juga dilakukan agar korban bisa beraktifitas kembali seperti sebelum terjadi kekerasan.

Kata kunci: Organisasi Perempuan, Kekerasan, Perempuan, Anak.

\section{Pendahuluan}

Kekerasan yang terjadi kepada perempuan dan anak merupakan suatu fenomena yang menjadi perbincangan akhir-akhir ini di beberapa daerah. Contohnya di Kabupaten Sidoarjo, seorang perempuan menjadi korban kekerasan yang dilakukan suaminya.1

Kekerasan terhadap perempuan dan anak merupakan isu yang paling sulit untuk dipahami sekaligus paling bermuatan emosi. Ini adalah isu yang paling personal, sekaligus paling politis juga. kekerasan dalam rumah tangga (KDRT) merupakan salah satu isu yang mendapat perhatian serius dari gerakan hak perempuan pada era reformasi hingga kini. Keseriusan perhatian terhadap isu KDRT ini didorong oleh kenyataan bahwa kekerasan apapun bentuk dan derajat keseriusannya dapat terjadi di dalam rumah. Orang yang dianggap dapat menjadi tempat berlindung ternyata justru menjadi penyebab malapetaka.2 Kenyataan seperti ini membantah anggapan umum masyarakat bahwa "lingkungan di luar rumah lebih berbahaya dari pada lingkungan di dalam rumah". Anggapan umum ini terbentuk oleh banyaknya pengungkapan dan publikasi kejahatan yang terjadi di luar lingkungan rumah, padahal lingkungan di dalam rumah tidak lagi secara otomatis merupakan tempat yang aman bagi anggota keluarga dan orang-orang yang tinggal di dalamnya untuk dapat berinteraksi dengan landasan kasih sayang, saling menghargai

1 Seperti kasus Natael Sopaheluwakan yang diputus bersalah oleh Pengadilan Negeri Sidoarjo karena menganiaya istrinya gara-gara merebutkan anak. "Pukul Istri, Natael Divonis $10 \quad$ Bulan", https://radarsurabaya.jawapos.com/read/2018/10/24/99940/pukul-istrinatael-divonis-10-bulan, diakses pada 26 Oktober 2018.

2 Widiartana, Kekerasan Dalam Rumah Tangga, Perspektif Perbandingan Hukum (Yogyakarta: Penerbit Universitas Atma Jaya, 2009), 1. 
dan menghormati. Sayangnya, masyarakat tidak menduga bahwa ternyata rumah dapat menjadi tempat yang paling mengerikan bagi anggota keluarga.

Kekerasan terhadap anak tidak kalah pentingnya untuk diperbincangkan. Anak adalah bagian yang tidak terpisahkan dari keberlangsungan hidup manusia dan keberlangsungan sebuah bangsa dan negara, agar kelak mampu bertanggung jawab dalam keberlangsungan bangsa dan negara. Setiap anak perlu mendapat perlindungan dan kesempatan yang seluas-luasnya untuk tumbuh dan berkembang secara optimal, baik fisik, mental, maupun sosial. Untuk itu, perlu dilakukan upaya perlindungan untuk mewujudkan kesejahteraan anak dengan memberikan jaminan terhadap pemenuhan hak-haknya tanpa adanya perlakuan diskriminatif. Dalam hal menjamin seorang anak agar kehidupannya bisa berjalan dengan normal, maka negara telah memberikan payung hukum yakni Undang-Undang Nomor 23 Tahun 2002 tentang Perlindungan Anak. Namun seiring berjalannya waktu, pada kenyataannya undang-undang tersebut dirasa belum dapat berjalan secara efektif karena masih adanya tumpang tindih antar peraturan perundang-undangan sektoral terkait dengan definisi anak.

Di sisi lain, maraknya kejahatan terhadap anak di tengah-tengah masyarakat, salah satunya adalah kejahatan seksual yang saat ini banyak dilakukan oleh orang-orang dekat sang anak, serta belum terakomodirnya perlindungan hukum terhadap anak penyandang disabilitas, sehingga berdasarkan paradigma tersebut maka UndangUndang Nomor 23 Tahun 2002 tentang Perlindungan Anak yang saat ini sudah berlaku \pm (kurang lebih) 12 (dua belas) tahun akhirnya diubah dengan Undang-Undang Nomor 35 Tahun 2014 tentang Perubahan Atas Undang-Undang Nomor 23 Tahun 2002 tentang Perlindungan Anak, yang mempertegas tentang perlunya pemberatan sanksi pidana dan denda bagi pelaku kejahatan terhadap anak terutama kepada kejahatan seksual yang bertujuan untuk memberikan efek jera, serta mendorong adanya langkah konkrit untuk memulihkan kembali fisik, psikis dan sosial anak. Hal tersebut perlu dilakukan untuk mengantisipasi anak (korban kejahatan) di kemudian hari tidak menjadi pelaku kejahatan yang sama. Karena berdasarkan fakta yang terungkap pada saat pelaku kejahatan 
terhadap anak (terutama pelaku kejahatan seksual) diperiksa di persidangan, ternyata sang pelaku dulunya juga pernah mengalami (pelecehan seksual) sewaktu sang pelaku masih berusia anak, sehingga sang pelaku terobsesi untuk melakukan hal yang sama sebagaimana yang pernah dialami.

Kekerasan adalah penggunaan kekuatan fisik dan kekuasaan, ancaman atau tindakan terhadap diri sendiri, perorangan atau sekelompok orang yang kemungkinan besar mengakibatkan memar atau trauma, kematian, kerugian psikologis, kelainan perkembangan, atau perampasan hak. Konsep kekerasan dalam hal ini adalah kekerasan fisik yang sering terjadi di masyarakat terutama terjadi pada perempuan. Kekerasan fisik sendiri merupakan bentuk gerakan fisik manusia untuk menyakiti tubuh dan merusak harta orang lain. Dampak kekerasan fisik bukan hanya berbentuk memar-memar atau yang terlihat oleh kasat mata, tetapi juga dampak psikis yang dapat mengakibatkan korban mengalami traumatik. Dalam konsep kekerasan itu sendiri terdapat 4 kategori, yaitu kekerasan fisik, kekerasan simbolik, kekerasan birokratik, dan kekerasan struktural.

Kekerasan Dalam Rumah Tangga (KDRT) yang dilakukan suami terhadap istri merupakan teror terhadap perempuan yang paling banyak terjadi di berbagai negara. Sekitar 20-67 pesen perempuan pernah mengalaminya, baik di negara berkembang maupun di negara maju.3 Kasus pemukulan suami terhadap isteri atau orang tua terhadap anak diselesaikan dengan menggunakan pasal tentang penganiayaan, yang kemudian sulit sekali dipenuhi unsur-unsur pembuktiannya, sehingga kasus yang diadukan tidak lagi ditindaklanjuti. Di sisi lain, doktrin agama dan adat menempatkan perempuan korban KDRT dalam situasi yang sulit untuk keluar dari lingkar kekerasan yang dialaminya untuk mendapatkan dukungan dari keluarga maupun komunitas. Keyakinan "berdosa" jika menceritakan "kejelekan" suami membuat banyak perempuan korban KDRT menyimpan dalamdalam berbagai bentuk kekerasan yang dialaminya.

3 Ester Lianawati, Tiada Keadilan Tanpa Kepedulian (KDRT Perspektif Psychologi Feminis), (Tk.: Paradigma Indonesia, 2009), 1. 
Jumlah kekerasan terhadap perempuan dan anak di Sidoarjo cenderung mengalami peningkatan, setiap tahun angka kekerasan tersebut meningkat antara 10-15 persen.4 Kondisi ini menunjukkan bahwa tingkat kekerasan terhadap perempuan dan anak di Sidoarjo tergolong tinggi. Kasus kekerasan yang banyak terjadi adalah kekerasan Dalam Rumah Tangga, KDRT dibedakan menjadi dua yakni Kekerasan Terhadap Istri (KTI) dan Kekerasan Terhadap Anak (KTA). Dari dua hal tersebut, kekerasan terhadap anak lebih tinggi dibandingkan dengan kekerasan terhadap perempuan, kasus pencabulan masih mendominasi dalam kasus kekerasan terhadap anak.5 Kasus kekerasan terhadap anak ini bisa terjadi dengan bebagai cara dan tempat, bisa datang dari dalam rumah sendiri maupun dari luar rumah, menurut keterangan dari P2TP2A Sidoarjo, kasus pencabulan terhadap anak ini banyak dilakukan oleh orang dekat korban.6

Budaya yang ada di masyarakat cenderung pasif dalam melaporkan tindak kekerasan dalam rumah tangganya. Perempuan atau anak yang menjadi korban KDRT lebih memilih diam, tidak melaporkan karena malu dan takut terjadi dampak negatif atas tindakan laporannya tersebut. Ketergantungan ekonomi juga menyebabkan korban memilih membenamkan peristiwa yang dialaminya itu. Sehingga laporan sering terhenti di tengah jalan karena keinginan korban. Masyarakat di lingkungan masingmasingpun kurang proaktif melaporkan terjadinya KDRT, padahal tindak kekerasan dalam rumah tangga bukan merupakan persoalan individu saja tetapi sudah menjadi persoalan bangsa, mengingat dampaknya yang sangat buruk bagi korban, bukan saja secara fisik tetapi juga secara psikis.

KDRT yang lebih banyak terkait dengan kekerasan terhadap perempuan, didefinisikan sebagai "suatu tindakan kekerasan berbasis gender dapat mengakibatkan bahaya atau penderitaan fisik, seksual atau mental perempuan termasuk ancaman tindakan sejenis,

4 htps://informasisidoarjo.wordpress.com/2012/11/16/kekerasan-padaperempuan-dan-anak-meningkat-di-sidoarjo/ diakses pada 21 Juli 2018.

5 Ibid.

$6 \mathrm{Hj}$. As'alut Thoyibah, S.PdI, Biro Pendampingan Korban P2TP2A Sidoarjo, Wawancara, Sidoarjo, 16 Juli 2018. 
pemaksaan atau perampasaan kebebasan secara sewenang-wenang, baik terjadi di ranah publik maupun kehidupan pribadi”. Belum maksimalnya penanganan terhadap korban KDRT karena bermacam sebab, di antaranya adalah selain kurang paham dan tidak tega menghukum pelaku yang kebanyakan orang terdekatnya, juga kurang adanya sosialisasi mengenai KDRT. Sehingga sampai saat ini jumlah KDRT di Kabupaten Sidoarjo misalnya menunjukkan angka kenaikan.

Sejak tahun 2004, Indonesia memiliki UU No. 23 Tahun 2004 tentang Penghapusan Kekerasan Dalam Rumah Tangga (UU PKDRT) yang mulai diberlakukan pada tahun 2005. Tahun 2004 merupakan momen yang sangat penting bagi perempuan, khususnya mereka yang terlibat dalam isu KDRT. Kehadiran UU PKDRT dengan tegas menyatakan tindakan kekerasan fisik, psikologis, seksual dan penelantaran yang dilakukan di dalam lingkup rumah tangga sebagai sebuah tindakan pidana. Bahkan Undang-Undang ini melindungi hak perempuan untuk bebas dari marital rape atau pemerkosaan dalam perkawinan. Undang-Undang ini selain dilengkapi dengan pengaturan sanksi yang salah satunya adalah berupa konseling, juga dengan hukum acaranya, karena KDRT merupakan isu yang membutuhkan penanganan khusus. Termasuk di dalamnya adalah tentang kewajiban negara memberikan perlindungan segera kepada korban yang melapor. Ini adalah sebuah terobosan hukum yang sangat penting bagi upaya penegakan HAM pada umumnya, mengingat sampai hari ini pun belum ada lagi sistem perlindungan untuk saksi dan korban.

Terobosan lainnya dalam UU PKDRT ini adalah laporan tertulis hasil pemeriksaan korban atau visum et repertum atau surat keterangan medis dianggap memiliki kekuatan hukum yang sama sebagai alat bukti. Korban pun dapat melaporkan secara langsung kekerasan yang dialaminya di tempat korban berada maupun di tempat kejadian perkara. Hal yang juga penting adalah diakuinya keterangan seorang saksi korban sebagai salah satu alat bukti yang sah apabila disertai dengan satu alat bukti yang sah lainnya. Dengan adanya UU PKDRT, isu kekerasan di dalam rumah tangga menjadi isu publik. Hal ini juga dapat dilihat dengan peningkatan jumlah kasus KDRT yang dilaporkan. Catatan tahunan Komnas 
Perempuan sejak tahun 2001-2007 menunjukkan peningkatan pelaporan sebanyak 5 kali lipat. Sebelum UU PKDRT, yaitu dalam rentang 2001-2004, jumlah yang dilaporkan sebanyak 30.139 kasus. Sejak diberlakukannya UU PKDRT, selama tahun 2005-2007, terhimpun sebanyak 68.425 kasus KDRT yang dilaporkan.

Terkait perlindungan anak, Undang-undang di Indonesia memberikan perlindungan dan ketentuan-ketentuan lain terkait anak yakni dalam undang-undang nomor 23 tahun 2002 tentang Perlindungan Anak.

Kasus KDRT yang terjadi di Kabupaten Sidoarjo menempati urutan kedua di tingkat propinsi Jawa Timur setelah kasus KDRT yang terjadi di Kabupaten Malang. Temuan kasus KDRT di Kabupaten Sidoarjo selama lima tahun terakhir sejak 2010 menunjukkan perkembangan fluktuatif. Pada tahun 2010, ada 137 kasus, tahun 2011 ada 102 kasus, tahun 2012 ada 120 kasus, tahun 2013 ada 95 kasus dan pada tahun 2014 ada 106 kasus. Dengan data ini dapat dikatakan bahwa jumlah kejadian tindak kekerasan terhadap perempuan dan anak pada tahun 2010 dibandingkan dengan tahun 2011 menunjukkan angka penurunan dari 137 kasus menjadi 102 kasus yakni menurun 35 kasus. Jumlah kejadian itu mengalami peningkatan sebanyak 18 kasus pada tahun 2012, dari 102 kasus pada tahun 2011 menjadi 120 kasus pada tahun 2012. Kemudian angka kejadian tersebut menurun pada tahun 2013 sebanyak 25 kasus dari 120 kasus pada tahun 2012 menjadi 95 kasus pada tahun 2013. Akan tetapi, jumlah kejadian tindak kekerasan tersebut meningkat lagi sebanyak 11 kasus atau 11,6\% dari 95 kasus pada 2013 menjadi 106 kasus pada 2014. Apabila dibandingkan dengan target RPJMD tahun 2014 sebesar 152 kasus maka terjadi penurunan sebanyak 46 kasus atau 30,3\%.7

Untuk kasus kekerasan di Sidoarjo tahun 2016 mencapai 133 kasus, yang berdasarkan jumlah akumulasi data dari seluruh kecamatan yang ada di Sidoarjo. Jumlah kasus kekerasan pada perempuan dan anak tersebut berdasarkan laporan dari masyarakat dan orang tua korban. Keberanian masyarakat untuk melaporkan

7 Sumber data: BPMPKB Kabupaten Sidoarjo. 
segala bentuk kekerasan yang terjadi pada perempuan dan anaknya masing-masing merupakan salah satu wujud kerjasama orang tua dengan badan pemberdayaan. 8

Pemerintan Kabupaten Sidoarjo sendiri telah mempunyai Perda nomor 18 tahun 2006 tentang penyelenggaraan, perlindungan perempuan dan anak, dengan harapan agar masyarakat lebih memahami hak perempuan dan anak, sehingga angka kekerasan terhadap perempuan dan anak bisa mengalami penurunan.

Di Sidoarjo terdapat berbagai macam organisasi perempuan, di antaranya Muslimat NU, Fatayat NU, IPPNU, Aisyiyah, kaukus perempuan Sidoarjo dan sebagainya. Organisasi-organisasi perempuan tersebut cukup terkenal di tengah masyarakat Sidoarjo. Organisasi-organisasi perempuan tersebut secara umum mempunyai visi terkait keadilan dan penghapusan kekerasan terhadap perempuan dan anak. Misalnya, Fatayat NU yang merupakan salah stau organisasi perempuan yang di bawah naungan Nahdlatul Ulama', merupakan salah satu wadah berkumpulnya pemudi pemudi Nahdlatul Ulama' yang didirikan pada tanggal 7 Rajab 1369 H bertepatan dengan tanggal 24 April 1950 M.9 Visi Fatayat NU yaitu "Terhapusnya segala bentuk kekerasan, ketidakadilan dan kemiskinan dalam masyarakat dengan mengembangkan wacana kehidupan sosial yang konstruktif, demokratis dan berkeadilan gender". Adapun pelaksanaan programnya mengacu pada misi Fatayat NU yaitu "membangun kesadaran kritis perempuan untuk mewujudkan kesetaraan dan keadilan gender". 10

Berdasarkan latar belakang tersebut penulis tertarik untuk meneliti peran organisasi perempuan Sidoarjo dalam merespon kekerasan terhadap perempuan dan anak di Sidoarjo.

\section{Kekerasan terhadap Perempuan}

8 http://www.antarajatim.com/lihat/berita/177631/pemkab-sidoarjo-antisipasikekerasan-anak, diakses pada tanggal 22 September 2016.

9 Peraturan Dasar dan Peraturan Rumah Tangga Fatayat Nahdlatul Ulama' Bab 1

Pasal 1

10 Ibid. 
Kekerasan adalah kata yang diterjemahkan dari violence, yang dalam bahasa latin disebut violentia. Sedangkan violence merupakan gabungan dari kata latin vis yang artinya adalah daya, kekuatan, dan kata latus yang berasal dari ferre (membawa) yang kemudian berarti membawa kekuatan.11 Menurut Kamus Besar Bahasa Indonesia, kekerasan adalah perihal atau sifat keras, paksaan, perbuatan seseorang atau sekelompok orang yang menyebabkan cedera atau matinya orang lain.12

Kekerasan terhadap perempuan adalah setiap perbuatan berdasarkan perbedaan kelamin yang mengakibatkan kesengsaraan dan penderitaan terhadap seorang perempuan secara fisik, seksual atau psikologis, termasuk ancaman tertentu, pemaksaan atau perampasan kemerdekaan secara sewenang-wenang, baik yang terjadi di depan umum atau dalam kehidupan pribadinya.13

Menurut Pasal 1 Undang-Undang Republik Indonesia Nomor 23 Tahun 2004 tentang Penghapusan Kekerasan Dalam Rumah Tangga, kekerasan rumah tangga adalah setiap perbuatan terhadap seseorang terutama perempuan yang berakibat timbulnya kesengsaraan atau penderitaan secara fisik, seksual, psikologis dan penelantaran rumah tangga termasuk ancaman untuk melakukan perbuatan pemaksaan atau perampasan kemerdekaan secara melawan hukum dalam lingkup rumah tangga.14

Selanjutnya pada pasal 2 ayat 1 undang-undang tersebut menyebutkan bahwa lingkup rumah tangga dalam Undang-Undang ini meliputi suami, isteri, dan anak (termasuk anak angkat dan anak tiri), orang-orang yang mempunyai hubungan keluarga baik hubungan darah, perkawinan, persusuan, pengasuhan, dan perwalian yang menetap dalam rumah tangga (mertua, menantu, ipar dan besan), dan orang yang bekerja membantu rumah tangga dan menetap dalam rumah tangga tersebut (Pekerja Rumah Tangga).

\footnotetext{
11 Johan Galtung, Kekuasaan dan Kekerasan menurut Johan Galtung, (Yogyakarta: Penerbit Kanisius, 1992), 62.

12 Depdikbud, Kamus Besar Bahasa Indonesia, (Jakarta: Balai Pustaka, 1988), 758.

13 Moerti Hadiati Soeroso, Kekerasan dalam Rumah Tangga dalam Perspektif Yuridis Viktimologis, (Jakarta: Sinar Grafika, 2010), 60.

14 Undang-Undang Republik Indonesia Nomor 23 Tahun 2004 Tentang Penghapusan Kekerasan Dalam Rumah Tangga.
} 
Berdasarkan pengertian kekerasan yang disebutkan di atas, sudah jelas bahwa penekanannya adalah perempuan dalam rumah tangga. Kekerasan terhadap perempuan dalam rumah tangga tidak mesti terjadinya di dalam rumah tangga itu sendiri, bisa saja kejadiannya di luar rumah tangga. Namun yang terpenting, baik pelaku maupun korbannya adalah berada dalam ikatan rumah tangga atau anggota rumah tangga.

\section{Bentuk-bentuk Kekerasan terhadap Perempuan Menurut UU PKDRT}

Kekerasan terhadap perempuan dapat terjadi terhadap seluruh ruang lingkup hubungan sosialnya, termasuk dalam hubungan keluarga, dalam hubungan kerjanya, maupun hubungan sosial kemasyarakatan yang lainnya. Kekerasan itu juga dapat terjadi pada seorang perempuan di mana saja, baik di ruang publik maupun dalam rumah tangganya.

Bentuk-bentuk kekerasan terhadap perempuan yang terdapat dalam Undang-undang Penghapusan Kekerasan Dalam Rumah Tangga Nomor 23 Tahun 2004 tertuang dalam Pasal 5 sampai dengan pasal 9, yaitu sebagai berikut:15

Pasal 5:

Setiap orang dilarang melakukan kekerasan dalam rumah tangga terhadap orang dalam lingkup rumah tangganya, dengan cara:

a. Kekerasan fisik.

b. Kekerasan psikis.

c. Kekerasan seksual atau.

d. Penelantaran rumah tangga.

\section{Kekerasan terhadap Anak}

Pengertian anak menurut Pasal 1 Ayat (1) Undang-Undang No. 35 Tahun 2014 Tentang Perubahan Atas Undang-Undang No. 23 Tahun 2002 Tentang Perlindungan Anak, adalah seseorang yang belum berusia 18 (delapan belas) tahun, termasuk anak yang masih dalam kandungan.

15 Undang-Undang Republik Indonesia Nomor 23 Tahun 2004 Tentang Penghapusan Kekerasan Dalam Rumah Tangga. 
Menurut Nicholas, sebagaimana yang dikutip oleh Sihombing dalam buku Kekerasan Terhadap Masyarakat Marjinal, mengatakan anak yaitu periode di antara kelahiran dan permulaan kedewasaan. Masa ini merupakan masa perkembangan hidup dan juga masa dalam keterbatasan kemampuan termasuk keterbatasan untuk membahayakan orang lain.16

Sedangkan yang dimaksud dewasa menurut Gultom adalah sesorang yang cukup umur untuk berketurunan dan muncul tanda laki-laki dewasa pada putra dan muncul tanda-tanda wanita dewasa pada putri. Inilah dewasa yang wajar yang biasanya belum ada sebelum anak putra berumur dua belas tahun dan putri berumur sembilan tahun. Apabila anak mengatakan bahwa ia sudah dewasa, keterangannya dapat diterima karena dia sendiri yang mengalaminya. Apabila sudah melewati usia tersebut di atas tetapi belum nampak tanda-tanda yang menunjukkan bahwa ia telah dewasa, harus ditunggu sampai ia berumur lima belas tahun.17

\section{Bentuk-bentuk Kekerasan terhadap Anak}

Kekerasan terhadap anak dikenal dengan istilah abuse, yaitu kata yang biasa diartikan dengan kekerasan penganiayaan, penyiksaan, atau perlakuan yang salah. Kekerasan terhadap anak adalah perbuatan disengaja yang menimbulkan kerugian atau bahaya terhadap anak-anak secara fisik maupun emosional. Istilah child abuse meliputi berbagai macam bentuk tingkah laku, dari tindakan ancaman fisik secara langsung oleh orang tua atau orang dewasa lainnya sampai kepada penelantaran kebutuhan-kebutuhan dasar anak. 18

Istilah child abuse sendiri dipakai untuk menggambarkan kasus anak-anak di bawah usia 16 tahun yang mendapat gangguan dari orang tua atau pengasuhnya dan merugikan anak secara fisik dan kesehatan mental serta perkembangannya.19 Menurut Barker,

16 Justin Sihombing, Kekerasan terhadap Masyarakat Marjinal, (Yogyakarta: Penerbit Narasi, 2005), 8-9.

17 Maidin Gultom, Perlindungan Hukum terhadap Anak dalam Sistem Peradilan Pidana Anak di Indonesia, (Bandung: PT. Refika Aditama, 2010), 31.

18 Abu Huraerah, Kekerasan terhadap Anak, (Bandung: Nuansa, 2006), 36.

19 Bagong Suyanto dan Sri Sanituti, Krisis \& Child Abuse, (Surabaya: Airlangga University, 2002), 114. 
kekerasan terhadap anak adalah tindakan melukai yang dilakukan secara berulang-ulang, baik berupa tindakan fisik maupun emosional terhadap anak yang ketergantungan melalui desakan hasrat, hukuman badan yang tak terkendali, degradasi dan cemoohan permanen atau kekerasan seksual. Hal ini biasanya dilakukan para orang tua atau pihak lain yang seharusnya merawat terhadap anak tersebut.20

Kekerasan terhadap anak (child abuse) ada empat bentuk, yaitu physical abuse (kekerasan secara fisik), psychological abuse (kekerasan secara psikologis), sexual abuse (kekerasan secara seksual), dan social abuse (kekerasan secara sosial).Kekerasan anak secara fisik, adalah penyiksaan, pemukulan, dan penganiayaan terhadap anak secara langsung atau dengan menggunakan benda-benda tertentu yang menimbulkan luka-luka fisik atau kematian pada anak. Kekerasan anak secara psikis, meliputi penghardikan, penyampaian kata-kata kasar dan kotor pada anak.

Kekerasan terhadap anak secara seksual dapat berupa perlakuan pra kontrak seksual antara anak dengan orang yang lebih besar, maupun perlakuan kontrak seksual secara langsung antara anak dengan orang dewasa. Sedangkan kekerasan secara sosial, dapat mencakup penelantaran anak dan eksploitasi anak. Seperti contoh misalnya, anak dikucilkan, diasingkan dari keluarga, atau tidak diberikan pendidikan dan perawatan kesehatan yang layak. Eksploitasi anak menunjukkan pada sikap diskriminatif atau perlakuan sewenang-wenang terhadap anak yang dilakukan keluarga atau masyarakat.21

Faktor penyebab terjadinya kekerasan dan penelantaran terhadap anak dibagi ke dalam tiga, yaitu sebagai berikut:22

1. Faktor Orang tua/Keluarga.

Faktor orang tua atau keluarga memegang peranan penting terhadap terjadinya kekerasan dan penelantaran kepada anak.

2. Faktor Lingkungan sosial/komunitas.

\footnotetext{
20 Abdul Wahid, Perlindungan terhadap Korban Kekerasan Advokasi atas Hak Asasi Perempuan, (Bandung: Refika Aditama, 2001), 31.

21 Abu Huraerah, Kekerasan terhadap Anak, 47-48.

22 Ibid., 40.
} 
Kondisi sosial dapat menjadi penyebab terjadinya kekerasan dan penelantaran terhadap anak. Lingkungan adalah berbagai faktor dan kondisi yang melingkupi dan mempengaruhi kehidupan seorang anak. Faktor lingkungan yang menyebabkan terjadinya kekerasan terhadap anak di antaranya kemiskinan, sosial ekonomi yang rendah, sosial ekonomi yang rendah, anggapan orang tua bahwa anak adalah milik orang tua sendiri, terlalu individualistis dan wanita masih dianggap dalam setatus yang rendah.

3. Faktor anak itu sendiri

Faktor yang menyebabkan terjadinya kekerasan dan penelantaran terhadap anak dari anak itu sendiri, yang antara lain enderita gangguan perkembangan, menderita penyebab penyakit kronis dan perilaku menyimpang pada anak.

\section{Respon Organisasi Perempuan di Sidoarjo}

Berikut dipaparkan repson organisasi perempuan di Sidoarjo terhadap kekerasan dan perempuan di Sidoarjo yang meliputi; Respon Pimpinan Cabang Fatayat NU Sidoarjo terhadap kekerasan perempuan dan anak di Sidoarjo, Respon Pimpinan Cabang Muslimat NU Sidoarjo terhadap kekerasan perempuan dan anak di Sidoarjo, Respon Pimpinan Cabang Aisyiyah NU Sidoarjo terhadap kekerasan perempuan dan anak di Sidoarjo, Respon Pimpinan Cabang Ikatan Pelajar Putri NU Sidoarjo terhadap kekerasan perempuan dan anak di Sidoarjo, dan Respon Pimpinan Daerah Nasyiatul Aisyiyah Sidoarjo terhadap kekerasan perempuan dan anak di Sidoarjo.

1. Respon Pimpinan Cabang Fatayat NU Sidoarjo terhadap kekerasan perempuan dan anak di Sidoarjo

Pimpinan Cabang Fatayat NU Sidoarjo memiliki beberapa program yang terkait dengan kekerasan terhadap perempuan dan anak yang terjadi di Sidoarjo. Sebagai organisasi perempuan, Fatayat hadir untuk menjawab problema yang terjadi di masyarakat, problem kekerasan terhadap perempuan dan anak ini dari tahun ke tahun grafiknya meningkat. Sidoarjo merupakan Kabupaten yang angka KDRT nya meningkat setiap tahun.

Trauma Healing merupakan salah satu upaya Pimpinan Cabang Fatayat NU Sidoarjo dalam merespon kekerasan 
terhadap perempuan dan anak. Dengan trauma bealing diharapankan korban kekerasan terhadap perempuan dan anak akan bisa kembali menjalani hidup secara normal dan survive.

Fatayat NU merupakan badan otonom NU yang bersifat keagamaan, kekeluargaan, sosial kemasyarakatan dan kebangsaan. Fatayat NU memiliki bidang garap perempuan usia produktif, sehingga menjadikan Fatayat NU dituntut untuk selalu dapat merespon segala kemungkinan yang terjadi. Fatayat NU memberikan perhatian khusus seputar hukum dan advokasi antara lain menegaskan supremasi hukum, penguatan hak perempuan dan kebutuhan dasar bagi kehidupan serta mewujudkan advokasi hukum di masyarakat.

Melalui bidang Hukum dan Advokasi, Pimpinan Cabang Fatayat NU Sidoarjo menetapkan beberapa program:

a. Melakukan kajian kritis terhadap berbagai kebijakan hukum dan politik terutama yang tidak berpihak pada kepentingan perempuan.

b. Menfasilitasi gerakan penyadaran hukum dan politik di masyarakat.

c. Mengembangkan jaringan dengan lembaga/instansi yang konsen dengan isu-isu perempuan.

d. Melakukan pemberdayaan perempuan dengan berbagai program seperti pendidikan politik untuk perempuan, peningkatan pendapatan keluarga dengan melibatkan perempuan.

e. Menfasilitasi terbentuknya forum dalam rangka mewujudkan ketahanan keluarga.

f. Menjalin kerjasama dengan instansi lain dalam pendampingan terhadap masyakat yang membutuhkan (berperkara).

Secara spisifik, memang tidak ditemukan program yang terkait kekerasan terhadap perempuan dan anak, akan tetapi secara praktik, Pimpinan Cabang Fatayat NU Sidoarjo telah banyak melakukan penanganan terhadap beberapa korban kekerasan terhadap perempuan dan anak, di antaranya adalah melakukan pendampingan untuk memberikan trauma healing pada korban kekerasan terhadap perempuan dan anak di Kecamatan Krembung. 
Respon Pimpinan Cabang Fatayat NU bukan hanya diinisiasi dari level cabang atau kabupaten, akan tetapi dari Pimpinan Pusat Fatayat juga memberikan spirit dalam melaksanakan program dampingan kepada korban kekerasan terhadap perempuan dan anak. Pimpinan pusat Fatayat NU melaunching program GELATIK (gerakan perlindungan anak Indonesia dari tindak kekerasan) di Kabupaten Brebes, yang harapannya seluruh Cabang atau Kabupaten mengikuti gerakan GELATIK tersebut.

Tidak mencantumkan secara langsung program yang terkait respon terhadap kekerasan perempuan dan anak memang menjadi sebuah catatan dan kurang jelas terkait program pendampingan terhadap korban. Disamping itu, respon Pimpinan Cabang Fatayat NU Sidoarjo lebih pada pendampingan sosial, bukan pendampingan hukum terhadap korban. Hal ini dipengaruhi oleh Sumber Daya Fatayat yang memang belum menyentuh para pakar di bidang Hukum dan Advokasi. Mereka yang menjabat sebagai pengurus Fatayat lebih banyak yang berkeahlian sebagai guru atau ibu rumah tangga, sehingga tidak bisa secara mendampingi korban pada ranah hukumnya.

Program ketahanan keluarga, ini adalah sebuah program yang datang dari instruksi pimpinan Fatayat wilayah Jawa Timur. Dengan program ketahanan keluarga harapannya bisa meminimalisir problema sosial yang terjadi di masyarakat. Keluarga merupakan pilar utama dalam menjaga keutuhan masyarakat, jika program ketahanan keluarga ini bisa dimaksimalkan, dengan menjaga keutuhan dan keharmonisan rumah tangga, niscaya problema sosial yang terjadi di tengan tengah masyarakat dapat diatasi.

Program ketahanan keluarga di Fatayat ini sangat penting sekali, karena kekerasan terhadap perempuan dan anak dapat terjadi di seluruh ruang lingkup hubungan sosial, termasuk dalam hubungan keluarga, dalam hubungan kerjanya, maupun hubungan sosial kemasyarakatan yang lainnya. Kekerasan itu juga dapat terjadi pada seorang perempuan di mana saja, baik di ruang publik maupun dalam rumah tangganya. 
Bentuk-bentuk kekerasan terhadap perempuan yang terdapat dalam Undang-undang Penghapusan Kekerasan Dalam Rumah Tangga Nomor 23 Tahun 2004 tertuang dalam Pasal 5 sampai dengan pasal 9, yaitu sebagai berikut:24

\section{Pasal 5:}

Setiap orang dilarang melakukan kekerasan dalam rumah tangga terhadap orang dalam lingkup rumah tangganya, dengan cara:

a. Kekerasan fisik

b. Kekerasan psikis

c. Kekerasan seksual atau

d. Penelantaran rumah tangga.

Pasal 6:

Kekerasan fisik sebagaimana dimaksud dalam Pasal 5 huruf (a) adalah perbuatan yang mengakibatkan rasa sakit, jatuh sakit, atau luka berat.

Pasal 7:

Kekerasan psikis sebagaimana dimaksud dalam Pasal 5 huruf $\mathrm{b}$ adalah perbuatan yang mengakibatkan ketakutan, hilangnya rasa percaya diri, hilangnya kemampuan untuk bertindak, rasa tidak berdaya, dan/atau penderitaan psikis berat pada seseorang.

Pasal 8:

Kekerasan seksual sebagaimana dimaksud dalam Pasal 5 huruf c meliputi:

a. Pemaksaan hubungan seksual yang dilakukan terhadap orang yang menetap dalam lingkup rumah tangga tersebut.

b. Pemaksaan hubungan seksual terhadap salah seorang dalam lingkup rumah tangganya dengan orang lain untuk tujuan komersial dan/atau tujuan tertentu.

Pasal 9:

a. Setiap orang dilarang menelantarkan orang dalam lingkup rumah tangganya, padahal menurut hukum yang berlaku baginya atau karena persetujuan atau perjanjian ia wajib

24 Undang-Undang Republik Indonesia Nomor 23 Tahun 2004 tentang Penghapusan Kekerasan Dalam Rumah Tangga. 
memberikan kehidupan, perawatan, atau pemeliharaan kepada orang tersebut.

b. Penelantaran sebagaimana dimaksud pada ayat (1) juga berlaku bagi setiap orang yang mengakibatkan ketergantungan ekonomi dengan cara membatasi dan/atau melarang untuk bekerja yang layak di dalam atau di luar rumah sehingga korban berada di bawah kendali orang tersebut.

Pimpinan Cabang Fatayat NU Sidoarjo bersinergi dengan P2TP2A Sidoarjo sebagai sebuah ikhtiyar dalam memperkuat program bidang Hukum dan Advokasi. Hal tersebut dikarenakan SDM Fatayat Cabang Sidoarjo dalam bidang hukum dan advokasi masih kurang. Misalnya dalam proses trauma bealing dibutuhkan seorang psikolog untuk mendampingi korban, SDM Fatayat tidak ada yang psikolog, maka P2TP2A menyediakan Psikolog.

Pimpinan Cabang Fatayat juga menugaskan salah satu kader terbaiknya untuk masuk dalam jajaran pengurus P2TP2A Sidoarjo. Dengan masuknya salah satu kader Fatayat Cabang Sidoarjo dalam jajaran kepengurusan di P2TP2A Sidoarjo, dapat memberikan nilai tambah, baik dari sisi pelayanan pada korban dan peningkatan wawasan dan peluang program yang bersinergi dengan pemerintah.

Secara umum Fatayat NU Sebagai organisasi perempuan menyadari bahwa di Sidoarjo banyak terjadi kasus kekerasan terhadap perempuan dan anak, yang hal tersebut memerlukan respon atau peran fatayat NU sebagai organisasi perempuan yang bersifat sosial, kemasyarakat dan kegamaan.

Secara struktural respon terhadap korban kekerasan ini tidak hanya di tingkat Cabang saja, akan tetapi lebih dari itu. Sejak tahun 2017, salah satu pengurus harian Pimpinan Fatayat pusat yang bernama Margareth Aliyatul Maimunah, M.Si. berhasil tepilih menjadi anggota komisioner KPAI (komisi Perlindungan Anak Indonesia). Margareth Aliyatul Maimunah merupakan sekretaris umum Pimpinan Pusat Fatayat NU.

Pimpinan Wilayah Fatayat NU juga sangat aktif mensosialisasikan ke cabang-cabang Fatayat NU yang berada di 
Jawa Timur dengan Program Ketahanan keluarga. Program ketahanan Keluarga ini akan bisa membentengi perempuan dan anak dari tindak kekerasan, setidaknya dapat dimulai dari komunitas terkecil yaitu keluarga.

2. Respon Pimpinan Cabang Muslimat NU Sidoarjo terhadap kekerasan perempuan dan anak di Sidoarjo

Dalam bidang Hukum dan Advokasi, Pimpinan Muslimat Cabang Sidoarjo memiliki jabaran program kerja sebagai berikut: a. Sosialisasi UU KDRT dan UU tentang Anak.

b. Mengadakan pelatihan terkait hukum dan advokasi.

c. Pendampingan advokasi korban kekerasan.

d. mewujudkan layanan konseling keluarga maslahah.

e. Membuat jaringan tingkat ke PAC/PRT.

Program tersebut sangat jelas memiliki keterkaitan dalam merespon kekerasan terhadap perempuan dan anak.

Menurut ketentuan Undang-undang yang berlaku, terdapat empat bentuk kekerasan terhadap perempuan, yaitu kekerasan fisik, psikis, seksual dan penelantaran rumah tangga. Kekerasan fisik yang dimaksud adalah perbuatan yang mengakibatkan rasa sakit, jatuh sakit, atau luka berat. Kekerasan psikis yang dimaksudkan ialah perbuatan yang mengakibatkan rasa ketakutan, hilangnya percaya diri dan hilangnya kemampuan untuk melakukan tindakan.

Maksud dari kekerasan seksual adalah pemaksaan hubungan seksual terhadap orang dalam lingkup rumah tangganya dan pemaksaan hubungan seksual terhadap salah seorang dalam lingkup rumah tangganya dengan orang lain dengan tujuan komersial atau tujuan lain. Sedangkan yang dimaksud penelantaran ialah penelantaran yang dapat mengakibatkan ketergantungan ekonomi dengan cara membatasi atau melarang untuk bekerja yang layak, baik di dalam rumah atau di luar rumah.

Untuk itu, dalam merespon fenomena yang terjadi di tengah masyarakat terkait dengan korban kekerasan terhadap perempuan dan anak, maka pimpinan Cabang Muslimat NU dengan berbagai progran yang ada di bidang advokasi dan hukum memberikan respon atau turut hadir dalam mendampingi para korban. 
Muslimat Cabang Sidoarjo secara jelas turut serta dalam menanggulangi korban kekerasan terhadap perempuan dan anak. Di samping itu, Pimpinan Cabang Muslimat NU memberikan sosialisasi tentang undang-undang kekerasan dalam rumah tangga di seluruh anggotanya, terbukti dengan adanya program sosialisasi UU KDRT di tiap ranting se cabang Sidoarjo.

Kekerasan terhadap anak dikenal dengan istilah abuse, yaitu kata yang biasa diartikan dengan kekerasan penganiayaan, penyiksaan, atau perlakuan yang salah. Kekerasan terhadap anak adalah perbuatan disengaja yang menimbulkan kerugian atau bahaya terhadap anak-anak secara fisik maupun emosional. Istilah child abuse meliputi berbagai macam bentuk tingkah laku, dari tindakan ancaman fisik secara langsung oleh orang tua atau orang dewasa lainnya sampai kepada penelantaran kebutuhankebutuhan dasar anak.25

Sebagaimana Fatayat NU, Muslimat NU juga bersinergi dengan lembaga P2TP2A dalam meangani korban, bahkan 2 kader terbaik Muslimat menjadi salah satu anggota pengurus P2TP2A Sidoarjo. Hal tersebut menunjukkan keikut sertan organisasi Muslimat NU cabang Sidoarjo dalam menangani korban kekerasan terhadap perempuan dan anak di Sidoarjo.

Pimpinan Cabang Muslimat NU Sidoarjo mempunyai perhatian lebih terhadap permasalahan perempuan di Sidoarjo, hal tersebut terlihat dari program kerja yang dirancang guna melindungi hak-hak perempuan dan anak. Untuk mendukung program tersebut Pimpinan Cabang Muslimat NU Sidoarjo bekerjasama dengan dinas terkait dalam rangka mensosialisasikan berbagai UU tentang perlindungan terhadap perempuan dan anak. Selain bentuk sosialisasi tentang UU, Pimpinan cabang Fatayat NU Sidoarjo juga memiliki rumah konseling bagi anggota yang memiliki masalah rumah tangga yang dikemas dalam bentuk "Layanan Konseling Rumah Tangga Maslahah".

Layanan Konseling Rumah Tangga Maslahah ini dibentuk oleh Pimpinan Cabang Muslimat NU Sidoarjo pada awal tahun 2018. Terbentuknya layanan konseling ini juga dalam rangka

25 Abu Huraerah, Kekerasan terhadap Anak, 36. 
memberikan pelayanan kepada kaum perempuan dan anak terutama bagi perempuan yang mengalami kekerasan dalam rumah tangga. Di samping itu, semakin banyaknya angka perceraian juga menjadi motifasi dari terbentuknya Layanan Konseling Rumah Tangga Maslahah PC Muslimat NU Sidoarjo.

Menyadari akan hal terbut, Muslimat NU Sidoarjo membentuk pusat konseling Keluarga Maslahah. Konseling keluarga maslahah ini lebih bersifat prefentif dalam menanggulangi problematika rumah tangga dan lebih jauh lagi mencegah adanya kemungkinan kekerasan dalam rumah tangga. Sedini mungkin persoalan yang muncul dalam rumah tangga, baik itu terkait dengan perempuan maupun terkait dengan anak bisa teratasi dengan baik.

Pasal 3 Undang-Undang No. 23 Tahun 2002 tentang Perlindungan Anak, menyatakan bahwa perlindungan anak bertujuan untuk menjamin terpenuhinya hak-hak anak agar dapat hidup, tumbuh, berkembang, dan berpartisipasi secara optimal sesuai dengan harkat dan martabat kemanusiaan, serta mendapat perlindungan dari kekerasan dan diskriminasi, demi terwujudnya anak Indonesia yang berkualitas, berakhlak mulia, dan sejahtera.27

Pimpinan Cabang Muslimat NU Sidoarjo juga memiliki perhatian khusus pada tenaga kerja perempuan yang rentan terjadinya tindak kekerasan. Melalui berbagai bentuk sosialisasi terhadap UU perlindungan tenaga kerja dan hak-hak tenaga kerja diharapkan perempuan dapat memainkan perannya sebagai tenaga kerja dengan lebih aman dan nyaman. Perhatian tersebut tidak hanya sebatas dengan sosialisasi seputar UU tetapi juga bersinergi dengan SARBUMISI Kabupaten Sidoarjo guna melindungi hak-hak tenaga kerja, dalam hal ini tenaga kerja wanita.28

Lebih jauh dapat dikatakan bahwa budaya yang ada di kalangan Muslimat Cabang Sidoarjo juga memperjuangkan kesetaraan gender. Tidak ada subordinasi terhadap perempuan.

27 Undang-Undang No. 23 Tahun 2002 tentang Perlindungan Anak.

28 Ibu Hj. Laily Agustin, SE, Wakil Sekretaris Pimpinan Cabang Muslimat NU Sidoarjo, Wawancara, Sidoarjo, 15 Oktober 2018. 
Muslimat NU sangat memahami tentang kesetaraan gender dalam Islam. Subordinasi terhadap perempuan yang merupakan suatu keyakinan yang berkembang di masyarakat ini tidak sesuai dan bertentangan dengan semangat keadilan yang diajarkan Islam. Di dalam al-Qur'an dinyatakan bahwa laki laki dan perempuan adalah sama-sama sebagai hamba:

Dan aku tidak menciptakan jin dan manusia melainkan supaya mereka mengabdi kepada-Ku. (Q.S. al-Dzariyat: 56).29

Muslimat NU Cabang Sidoarjo dalam menetapkan dan menjalankan organisasi sesuai dengan apa yanga menjadi visi dan misi organisasi:

Visi

Terwujudnya masyarakat sejahtera yang dijiwai ajaran Islam Ahlusunnah wal jamaah dalam Negara Kesatuan Republik Indonesia yang berkemakmuran dan berkeadilan yang diridloi Allah SWT.

Misi

a. Mewujudkan masyarakat Indonesia khususnya perempuan, yang sadar beragama, bermasyarakat, berbangsa dan bernegara.

b. Mewujudkan masyarakat Indonesia khususnya perempuan, yang berkualitas, mandiri dan bertaqwa kepada Allah SWT.

c. Mewujudkan masyarakat Indonesia khususnya perempuan, yang sadar akan kewajiban dan haknya menurut ajaran Islam baik sebagai pribadi maupun sebagai anggota masyarakat.

d. Melaksanakan tujuan Jam'iyyah NU sehingga terwujudnya masyarakat adil dan makmur yang merata dan diridhoi Allah SWT.

Untuk mencapai visi dan misi yang dimaksud dalam Pasal 4 dan 5 Muslimat NU menentukan strategi sebagai berikut:

a. Mempersatukan gerak kaum Perempuan Indonesia, khususnya Perempuan Islam Ahlussunah Wal Jama'ah.

29 Departemen Agama RI, Al-Qur'an Translitasi Latin Terjemah Indonesia, Jakarta: Suara Agung, 2012), 1090. 
b. Meningkatkan kualitas Perempuan Indonesia yang cerdas, trampil, dan kompetitif, sebagai bentuk tanggungjawab terhadap Agama, Bangsa, Negara dan membentuk generasi penerus bangsa yang taat beragama.

c. Bergerak aktif dalam kegiatan pelayanan masyarakat di bidang:

1) Peribadatan, dakwah, dan penerangan.

2) Sosial, ekonomi, kesehatan, dan lingkungan hidup.

3) Pendidikan.

4) Hukum dan Advokasi.

5) Usaha Kemasyarakatan lainnya yang tidak bertentangan dengan tujuan organisasi.

d. Meningkatkan jejaring dan kerjasama dengan badan-badan Lembaga/organisasi lain yang tidak bertentangan dengan visi dan misi organisasi.

3. Respon Pimpinan Cabang Aisyiyah NU Sidoarjo terhadap kekerasan perempuan dan anak di Sidoarjo.

Aisyiyah, organisasi perempuan Persyarikatan Muhammadiyah, merupakan gerakan Islam dan dakwah amar makruf nahi mungkar, yang berazaskan Islam serta bersumber pada al-Qur'an dan Assunnah.

Organisasi Aisyiyah mempunyai visi "Tegaknya agama Islam dan terwujudnya masyarakat Islam yang sebenar-benarnya". Visi Pengembangan Tercapainya usaha-usaba Aisyiyah yang mengarah pada penguatan dan pengembangan dakwah amar makruf nahi mungkar secara lebih berkualitas menuju masyarakat madani, yakni masyarakat Islam yang sebenar-benarnya.

Majelis Hukum dan HAM Pimpinan Daerah Aisyiyah Sidoarjo memiliki perhatian khusus terkait perlindungan terhadap kaum perempuan dan anak. Hal itu terbukti dengan berbagai program kerja yang merujuk pada perlindungan perempuan dan anak. Program kerja tersebut adalah:

a. Meningkatkan upaya advokasi hukum dan HAM dengan pola dan model pendampingan bagi masyarakat, secara umum khususnya yang termarginalkan termasuk pembelaan terhadap perempuan, anak dan tenaga kerja wanita yang bermasalah sebagai kelompok rentan. 
b. Meningkatkan kapasitas pimpinan Majelis Hukum dan HAM dalam melakukan kegiatan penyadaran hukum dan pendampingan advokasi bagi korban kekerasan dan pelanggaran hukum.

c. Melakukan pengkajian secara proaktif terhadap berbagai Rancangan Perundang-Undangan (RUU) dan Rancangan Peraturan Daerah (Raperda) yang merugikan perempuan dengan prespektif gender sesuai dengan nilai-nilai Islam untuk keadilan bagi semua pihak.

d. Meningkatkan kesadaran hukum di komunitas.

Organisasi Aisyiyah lebih tampak jelas keikutsertaannya dalam merespon kekerasan terhadap perempuan dan anak. Aisyiyah tidak hanya mendampingi korban saja, tetapi juga memberikan pelayanan hukum terhadap korban kekerasan. Secara preventif organisasi Aisyiyah juga mengkaji Rancangan Undang undang dan Rancangan Peraturan Daerah (Raperda) yang merugikan perempuan dengan perspektif gender sesuai dengan nilai nilai Islam untuk keadilan semua pihak.

Selain itu pimpinan daerah Aisyiyah Sidoarjo memiliki perhatian khusus bagi korban kekerasan terhadap perempuan dan anak berupa "Aisyiyah Family Care" yang mendampingi dan memberikan trauma healing bagi mereka yang mengalami gangguan psikis pasca terjadinya tindak kekerasan. Majelis Hukum dan HAM Pimpinan Daerah Aisyiyah Sidoarjo memiliki tim khusus yang di dalamnya terdiri atas para lanyer yang bersedia dan sanggup melakukan pendampingan dan pembelaan hingga ke pengadilan. Telah banyak kasus yang berhasil ditangani oleh tim yang bernaung di majlis hukum dan HAM Pimpinan Daerah Aisyiyah Sidoarjo.

Aisyiyah Family Care, adalah suatu ikhtiyar organisasi Aisyiyah yang secara jelas memberikan layanan bagi warga yang mengalami kekerasan, baik perempuan maupun anak. Bentuk pelayanan itu adalah memberikan trauma healing bagi korban yang mengalami gangguan psikis pasca terjadinya tindak kekerasan.

Aisyiyah dalam menangani korban kekerasan dilakukan secara mandiri dan telah banyak kasus yang sudah ditangani. Aisyiyah mampu menangani secara mandiri dengan melibatkan 
lawyer yang bersedia dan sanggup melakukan pendampingan dan pembelaan hingga ke pengadilan.

Program Aisyiyah tersebut sesuai dengan langkah pemerintah Indonesia yang memberikan perhatian secara serius terhadap kesejahteran dan tindak kekerasan terhadap anak. Hal ini bisa diperhatikan, bahwa mulai tahun 1979 pemerintah telah menetapkan sebuah peraturan untuk meletakkan anak-anak dalam sebuah lembaga proteksi yang cukup aman, yaitu UndangUndang No. 4 Tahun 1979 tentang Kesejahteraan Anak yang dengan tegas merumuskan, setiap anak berhak atas pemeliharaan dan perlindungan sejak dalam kandungan sampai dengan sesudah dilahirkan.

4. Respon Pimpinan Cabang Ikatan Pelajar Putri NU Sidoarjo terhadap kekerasan perempuan dan anak di Sidoarjo

Sebagai organisasi pelajar, IPPNU lebih menekankan program kerja yang terkait dengan pengkaderan, baik formal maupun informal. Secara khusus IPPNU tidak memiliki program kerja terkait penelitian, namun pada dasarnya IPPNU juga memiliki kepedulian akan adanya perlindungan terhadap perempuan dan anak.

Tingginya kasus kekerasan pada perempuan dan anak di Sidoarjo menimbulkan keprihatinan bagi sesama perempuan khususnya organisasi yang anggotanya adalah perempuan seperti IPPNU ini. Namun aksi nyata yang dilakukan IPPNU Sidoarjo selama ini hanya sebatas rasa empati yang tertuang dalam tulisan di media sosial. Tulisan tersebut adalah salah satu bentuk perhatian sekaligus protes terhadap lembaga hukum dan HAM jika terjadi ketidak adilan pada kaum perempuan.

Rasa empati terhadap korban kekerasan dalam rumah tangga yang dituangkan dalam media sosial ini merupakan salah satu bentuk dakwah yang sesuai dengan kapasitas organisai pelajar putri.

Rasa empati melaui media sosial bisa menjadi sarana edukasi bagi masyarakat secara umum, agar masyarakat waspada bahwa kekerasan terhadap perempuan dan anak itu bisa terjadi di berbagai tempat, bahkan dari lingkungan keluarga juga sangat mungkin akan terjadi kekerasan terhadap perempuan dan anak. 
Menyampaikan rasa empati melalui media sosial dapat dimaknai merupakan salah satu bentuk pertanggung jawaban sebagai khalifah di muka bumi ini.

5. Respon Pimpinan Daerah Nasyiatul Aisyiyah Sidoarjo terhadap kekerasan perempuan dan anak di Sidoarjo

Program kerja terkait dengan adanya respon organisasi perempuan terhadap tindak kekerasan pada perempuan dan anak dilakukan oleh Departemen Advokasi Perlindungan Wanita Dan Anak. Program kerja tersebut berupa :

a. Talk show "Kenakalan Remaja".

b. Sosialisasi Kesehatan alat reproduksi wanita.

c. Sosialisasi Perlindungan diri dari Pelecehan seksual.

Dari beberapa program kerja Nasyiatul Aisyiyah, tampak bahwa meskipun tidak ada program secara jelas dalam penanganan korban kekerasan terhadap perempuan dan anak, akan tetapi beberapa program yang ada mengarah kepada tindakan preventif terhadap terjadinya tindak kekerasan dalam rumah tangga. Penanganan secara preventif lebih efektif untuk dilaksanakan, mengingat program program yang bersifat preventif akan lebih mudah diterima oleh masyarakat secara umum.

Kekerasan terhadap perempuan dapat terjadi terhadap seluruh ruang lingkup hubungan sosialnya, termasuk dalam hubungan keluarga, dalam hubungan kerjanya, maupun hubungan sosial kemasyarakatan yang lainnya. Kekerasan itu juga dapat terjadi pada seorang perempuan dimana saja, baik di ruang publik maupun dalam rumah tangganya.

Nasyiatul Aisyiyah memulai dengan memberikan edukasi kepada para remaja terkait kenalakalan remaja dan perlindungan diri terhadap tindak kekerasan. Program program yang telah ditetapkan oleh pengurus daerah Nasyiatul Aisyiyah lebih ditujukan kepada para remaja perempuan dan para pelajar.

\section{Penutup}

Dalam penelitian ini, dapat disimpulkan bahwa Fatayat NU, Muslimat NU, Aisyiyah, Nasyi'atul Aisyiyah dan IPPNU mempunyai peran yang penting dalam ikut serta menangani kasus kekerasan terhadap perempuan dan anak yang terjadi di Sidoarjo. 
Fatayat NU, Muslimat NU, Aisyiyah, Nasyi'atul Aisyiyah dan IPPNU menyadari bahwa organisasi perempuan haruslah merespon terhadap perkembangan dan kebutuhan masyarakat, organisasi perempuan yang merupakan bagian dari masyarakat sudah sepatutnya untuk ikut serta bersama pemerintah menangani korban kekerasan terhadap perempuan dan anak yang ada di Sidoarjo. Penanganan kasus kekerasan terhadap perempuan dan anak tidak hanya persoalan perlindungan hukum saja, akan tetapi pendampingan trauma healing terhadap korban juga sangat diperlukan agar supaya korban bisa beraktifitas seperti sebelum terjadi kekerasan.

Adapun program dan kegiatan organisasi perempuan di Sidoarjo yang merespon kekerasan terhadap perempuan dan anak di Sidoarjo adalah sebagai berikut:

a. Fatayat NU: dalam bidang Advokasi dan hukum terdapat program pendampingan terhadap perempuan atau anak yang menjadi korban kekerasan dalam rumah tangga. Fatayat NU bekerjasama dengan P2TP2A untuk memberikan trauma healing terhadap korban. Bahkan Pimpinan Pusat Fatayat NU menginstruksikan adanta GELATIK (gerakan perlindungan anak Indonesia dari tindak kekerasan). Di samping itu Pimpinan Wilayah Fatayat NU juga menginstruksikan agar seluruh kegiatan berbasis "Ketahanan Keluarga" sebagai langkah preventif.

b. Muslimat NU: Dalam bidang hukum dan advokasi, Pimpinan Muslimat Cabang Sidoarjo memiliki Jabaran Program kerja sebagai berikut: Sosialisasi UU KDRT dan UU tentang Anak, Mengadakan pelatihan terkait hukum dan advokasi, pendampingan advokasi korban kekerasan, mewujudkan layanan konseling keluarga Maslahah, membuat jaringan tingkat ke PAC/PRT. Muslimat NU juga bersinergi dengan P2TP2A Sidoarjo.

c. Aisyiyah: Majelis Hukum dan HAM Pimpinan Daerah Aisyiyah Sidoarjo memiliki perhatian khusus terkait perlindungan terhadap kaum perempuan dan anak. Hal itu terbukti dengan berbagai program kerja yang merujuk pada perlindungan perempuan dan anak. Program kerja tersebut adalah: Meningkatkan upaya advokasi hukum dan HAM dengan pola 
dan model pendampingan bagi masyarakat, meningkatkan kapasitas pimpinan Majelis Hukum dan HAM dalam melakukan kegiatan penyadaran hukum dan pendampingan advokasi bagi korban kekerasan dan pelanggaran hukum, melakukan pengkajian secara proaktif terhadap berbagai Rancangan Perundang-Undangan (RUU) dan Rancangan Peraturan Daerah (Raperda) yang merugikan perempuan dengan prespektif gender sesuai dengan nilai-nilai Islam untuk keadilan bagi semua pihak. Selain itu pimpinan daerah Aisyiyah Sidoarjo memiliki perhatian khusus bagi korban kekerasan terhadap perempuan dan anak berupa "Aisyiyah Family Care" yang mendampingi dan memberikan trauma bealing bagi mereka yang mengalami gangguan psikis pasca terjadinya tindak kekerasan.

d. IPPNU: Tingginya kasus kekerasan pada perempuan dan anak di Sidoarjo menimbulkan keprihatinan bagi sesama perempuan khususnya organisasi yang anggotanya adalah perempuan seperti IPPNU ini. Namun aksi nyata yang dilakukan IPPNU Sidoarjo selama ini hanya sebatas rasa empati yang tertuang dalam tulisan di media sosial. Tulisan tersebut adalah salah satu bentuk perhatian sekaligus protes terhadap lembaga hukum dan HAM jika terjadi ketidak adilan pada kaum perempuan.

e. Nasyiatul Aisyiyah: Program kerja terkait dengan adanya respon organisasi perempuan terhadap tindak kekerasan pada perempuan dan anak dilakukan oleh Departemen Advokasi Perlindungan Wanita Dan Anak. Program kerja tersebut berupa: Talk show "Kenakalan Remaja", sosialisasi Kesehatan alat reproduksi wanita, sosialisasi perlindungan diri dari pelecehan seksual.

\section{Daftar Pustaka}

Abdul Wahid, Perlindungan Tterhadap Korban Kekerasan Advokasi atas Hak. Asasi Perempuan, Bandung: Refika Aditama, 2001.

Abu Huraerah, Kekerasan terbadap Anak, Bandung: Nuansa, 2006.

Hj. As'alut Thoyibah, S.PdI, Biro Pendampingan Korban P2TP2A Sidoarjo, Wawancara, Sidoarjo, 16 Juli 2018.

Bagong Suyanto dan Sri Sanituti, Krisis \& Child Abuse, Surabaya: Airlangga University, 2002. 
Ester Lianawati, Tiada Keadilan Ttampa Kepedulian (KDRT Perspektif Psychologi Feminis), Tk.: Paradigma Indonesia, 2009.

Johan Galtung, Kekuasaan dan Kekerasan menurut Johan Galtung, Yogyakarta: Penerbit Kanisius, 1992.

Justin Sihombing, Kekerasan Terhadap Masyarakat Marjinal, Yogyakarta: Penerbit Narasi, 2005.

Ibu Hj. Laily Agustin, SE, Wakil sekretaris Pimpinan Cabang Muslimat NU Sidoarjo, Wawancara, Sidoarjo, 15 Oktober 2018.

Maidin Gultom, Perlindungan Hukum Tterhadap Anak dalam Sistem

Peradilan Pidana Anak di Indonesia, Bandung: PT. Refika Aditama, 2010.

Moerti Hadiati Soeroso, Kekerasan dalam Rumah Tangga dalam Perspektif Yuridis Viktimologis, Jakarta: Sinar Grafika, 2010.

Widiartana, Kekerasan dalam Rumah Tangga perspektif Perbandingan

Hukum, Yogyakarta: Penerbit Universitas Atma Jaya, 2009.

Undang-Undang Republik Indonesia Nomor 23 Tahun 2004

Tentang Penghapusan Kekerasan Dalam Rumah Tangga.

BPMPKB Kabupaten Sidoarjo.

Departemen Agama RI, Al-Qur'an Translitasi Latin Terjemah Indonesia, Jakarta: Suara Agung, 2012.

Depdikbud, Kamus Besar Bahasa Indonesia, Jakarta: Balai Pustaka, 1988.

Peraturan Dasar dan Peraturan Rumah Tangga Fatayat Nahdlatul Ulama'.

htps://informasisidoarjo.wordpress.com/2012/11/16/kekerasan-

pada-perempuan-dan-anak-meningkat-di-sidoarjo/

http://www.antarajatim.com/lihat/berita/177631/pemkab-

sidoarjo-antisipasi-kekerasan-anak, diakses pada tanggal 22 September 2016.

"Pukul Istri, Natael Divonis 10 Bulan", https://radarsurabaya.jawapos.com/read/2018/10/24/9994 0/pukul-istri-natael-divonis-10-bulan, diakses pada 26 Oktober 2018. 